Federal Reserve Bank of Dallas

Globalization and Monetary Policy Institute

Working Paper No. 65

http://www.dallasfed.org/assets/documents/institute/wpapers/2010/0065.pdf

\title{
Globalization and Inflation in Europe
}

\author{
Raphael Auer \\ Swiss National Bank \\ Kathrin Degen \\ University of Lausanne \\ Andreas M. Fischer \\ Swiss National Bank and CEPR
}

November 2010

\begin{abstract}
What is the impact of import competition from other low-wage countries (LWCs) on inflationary pressure in Western Europe? This paper seeks to understand whether laborintensive exports from emerging Europe, Asia, and other global regions have a uniform impact on producer prices in Germany, France, Italy, Sweden, and the United Kingdom. In a panel covering 110 (4-digit) NACE industries from 1995 to 2008, IV estimates predict that LWC import competition is associated with strong price effects. More specifically, when Chinese exporters capture 1\% of European market share, producer prices decrease about $2 \%$. In contrast, no effect is present for import competition from low-wage countries in Central and Eastern Europe.
\end{abstract}

JEL codes: F11, F12, F14, F16, F40

\footnotetext{
* Raphael Auer, Swiss National Bank, Börsenstrasse 15, P.O. Box Ch-8022 Zürich, Switzerland. 609-258-9375. raphael.auer@snb.ch. Kathrin Degen, Université de Lausanne, Quartier UNIL-Dorigny Bâtiment Internef, 1015 Lausanne, Switzerland. 021-692-35-76. Kathrin.Degan@unil.ch. Andreas Fischer, Swiss National Bank, Börsenstrasse 15, P.O. Box Ch-8022, Zürich, Switzerland. + 41-44-631-3294. andreas.fischer@snb.ch.. The views in this paper are those of the authors and do not necessarily reflect the views of the Swiss National Bank, the Federal Reserve Bank of Dallas or the Federal Reserve System.
} 


\section{Introduction}

Trade's impact with low-wage countries (LWCs) - and in particular with China - on industry structure and prices in developed economies is a contentious issue. ${ }^{1}$ Numerous researchers have attempted to determine whether imports from China held down European prices. ${ }^{2}$ A common finding is that trade with LWCs had only a mild effect at best on European prices. The objective of this paper is to demonstrate that the impact of LWC exports on European producer prices is much more pronounced and complex than is commonly assumed.

We argue that the existing literature fails to establish the causal effect

\footnotetext{
${ }^{1}$ See Mishkin (2007), Carney (2008), De Gregorio (2008), and Trichet (2008) for diverging views as to how central bank governors define the links between globalization and inflation.

${ }^{2}$ Micro studies using 2- and 4-digit PPI and CPI data include Bugamelli et al. (2010) for Italy (small price effect), Glatzer et al. (2006) for Austria (no price effect), WEO (2006) for Europe (no price effect), and Wheeler (2008) for the UK (no price effect). Borio and Filardo, (2007) and Pain et al. (2006) use more-conventional specifications of Phillips curves to determine the role of foreign output gaps on (aggregate) domestic inflation. A separate set of empirical studies including Auer and Fischer (2010), Ball (2006), Gamber and Hung (2001), Ihrig et al. (2007), Kamin et al. (2006), and Tootell (1998) focus exclusively on the U.S. case.
} 
of trade since trade flows are endogenous to local demand conditions. For example, when an industrial sector in Europe experiences a positive demand shock, prices increase, thereby inducing an increase in LWC imports. The presence of this endogeneity biases the estimated relative price effect from trade towards zero.

The paper's first contribution is to build on and extend the IV strategy of Auer and Fischer (2010) for the case of both heterogeneous exporter markets (here mostly: emerging Europe versus China) and heterogeneous import markets (Germany, France, Italy, Sweden, and the United Kingdom). As in Auer and Fischer (2010), the IV strategy is based on the simple observation that when LWC manufacturing output grows, LWC exports to Western Europe increase in labor intensive sectors relative to capital intensive sectors. Imports from LWCs are heavily concentrated in labor intensive industries. We show that this specialization also holds at the margin: for example, when China's manufacturing output rises, Chinese exports increase much more in labor-intensive sectors than in capital intensive sectors.

Because the aggregate growth of productive capacity in LWCs may be endogenous to European demand, we use a difference-in-difference specification to identify the causal effect of LWC imports on prices. We also introduce 
fixed effects to filter out sector specific trends in prices. The variation that is exploited relates the difference in how imports change in sectors with different labor intensities to differences in sectoral price changes. In addition to this identification strategy (based mostly on Auer and Fischer, 2010), in some specifications, we also utilize variation in how the latter supply-driven increase in imports affects various import markets differentially given their varying degree of openness to China and the other LWCs covered in this study.

A second contribution of the paper is to identify the global linkages of import competition on European prices. Beyond the main empirical findings that shows LWC trade has a profound relative price impact on European producer prices, we show that this result is largely driven by Chinese exports. More specifically, when Chinese exporters capture 1\% of European market share, producer prices decrease about $2 \%$. In contrast, no effect is present for import competition from low-wage countries in Central and Eastern European (CEE).

The paper's roadmap is as follows: Section 2 first discusses the empirical framework and the data in the context of LWC exports. Next, Section 3 presents OLS and IV estimates of LWC's impact on European producer 
prices. Thereafter, Section 4 disentangles the main empirical result of Section 3 by considering different regional constellations of LWC import competition. These include examining the role of China separately or alternatively the influence of CEE countries with an abundance of low-skilled labor. Section 5 offers concluding remarks on the global nature of labor-intensive goods and their implications for European prices.

\section{Empirical framework and data}

The discussion of the empirical framework is presented in three subsections. The regression model and the IV strategy are discussed in section 2.1. Instrument construction and preliminary first-stage regressions are presented in section 2.2. Data description and sources are offered in section 2.3.

\subsection{Empirical setup}

The true relation between European price changes and LWC import changes is given by

$$
\Delta p_{e, j, t}=\alpha_{p, j}+\beta \Delta m_{l w c, j, t}+\epsilon_{p, t}+\epsilon_{p, j, t},
$$

where $p_{e, j, t}$ denotes European prices at time $t$ for sector $j$ and $m_{l w c, j, t}$ denotes European imports in sector $j$ from LWCs. The industry-specific trend of Eu- 
ropean prices in sector $j$ is captured by $\alpha_{p, j}$, the common shock to European prices at time $t$ by $\epsilon_{p, t}$, and sector specific price shocks by $\epsilon_{p, j, t}$. The absolute change in a variable is denoted by $\Delta$.

In Equation (1), the coefficient of interest, $\beta$, measures the true impact of an increase in trade with LWCs on European sectoral prices. A prior shared by most researchers is that LWC imports lead to lower European prices, i.e., $\beta<0$.

It is evident that trade is endogenous to local demand conditions in equation (1). An OLS estimation of $\beta$ in Equation (1) is therefore biased. Apart from the unobserved export supply shocks in LWCs (denoted by $\Delta s_{l w c, j, t}$ below), European prices also influence how much foreign firms export. The relation between the change in LWC imports, European prices, and supply and demand conditions in LWCs is given by

$$
\Delta m_{l w c, j, t}=\alpha_{m, j}+\delta \Delta p_{e, j, t}+\theta \Delta s_{l w c, j, t}+\epsilon_{m, t}+\epsilon_{m, j, t}
$$

where $\alpha_{m, j}$ is an industry-specific trend of LWC imports, $\epsilon_{m, t}$ is a common shock to LWC exports to Europe, and $\epsilon_{m, j, t}$ is a sector-specific shock.

To solve the endogeneity problem, we observe that LWC exports to Europe are primarily in labor-intensive sectors and that the increase in exports 
is larger when aggregate LWC growth is high. We denote the LWC growth of manufacturing output by $g_{l w c}$ and a sector's (average) labor intensity by $\overline{l s}_{j}$. For most specifications presented below, we postulate that supply pressure in LWCs follows

$$
\Delta s_{m, j, t}=\alpha_{s, j}+\lambda_{1} g_{l w c, t}+\lambda_{2} g_{l w c, t} \overline{l s}_{j}+\epsilon_{s, t}+\epsilon_{s, j, t}
$$

where $\epsilon_{s, t}$ and $\epsilon_{s, j, t}$ are aggregate and sector-specific shocks.

Because aggregate growth in LWCs may still be correlated with aggregate demand in Europe, we do not use $\Delta s_{m, j, t}$ as an instrument for trade. Rather, we evaluate the difference of imports between two sectors $j$ and $k$ that differ in their labor intensities $\overline{l s}_{j}$ and $\overline{l s}_{k}$, yielding

$$
\Delta m_{l w c, j, t}-\Delta m_{l w c, k, t}=\frac{\theta \lambda_{2}}{1-\delta \beta}\left(\overline{l s}_{j}-\overline{l s}_{k}\right) g_{l w c, t}+\epsilon_{m, j, t}^{*}
$$

The reduced form relation between labor intensity differentials and price differentials is derived by substituting equation (4) into a similar difference-indifference version of equation (2). The reduced form difference-in-difference specification relating LWC growth changes, skill intensity to relative changes in prices becomes

$$
\Delta p_{e, j, t}-\Delta p_{e, k, t}=\alpha_{p_{k, j}}^{*}+\beta \frac{\theta \lambda_{2}}{1-\delta \beta}\left(\overline{l s}_{j}-\overline{l s}_{k}\right) g_{l w c, t}+\epsilon_{p_{k, j, t}}^{*}
$$


where

$$
\begin{aligned}
\epsilon_{p_{k, j, t}}^{*} & =\frac{1}{1-\delta \beta}\left(\left(\epsilon_{p, j, t}-\epsilon_{p, k, t}\right)+\beta\left(\epsilon_{m, j, t}-\epsilon_{m, k, t}\right) \beta \theta\left(\epsilon_{s, j, t}-\epsilon_{s, k, t}\right)\right) \\
\alpha_{p_{k, j}}^{*} & =\frac{1}{1-\delta \beta}\left(\left(\alpha_{p, j}-\alpha_{p, k}\right)+\beta\left(\alpha_{m, j}-\alpha_{m, k}\right)+\theta \beta\left(\alpha_{s, j}-\alpha_{s, k}\right)\right) .
\end{aligned}
$$

In Section 4.3, where we analyze the impact of import competition from CEE countries on prices in Western Europe, we refine our instrumentation strategy to also incorporate the fact that the CEE exporters may be more or less important in certain Western European markets in certain types of goods. For example, owing to the geographic proximity, these countries could be more important in Germany than in France for goods with high transportations costs. We thus weigh the instrument proposed in (3) by the lagged import share of the CEE exporters in each Western European importer (denoted by $m_{l w c, j, i, t-1}$ where $i$ denotes the importing nation), thus yielding

$$
\widetilde{\Delta s_{m, j, t}}=\left(\alpha_{s, j}+\lambda_{1} g_{l w c, t}+\lambda_{2} g_{l w c, t} \overline{l s}_{j}+\epsilon_{s, t}+\epsilon_{s, j, t}\right) m_{l w c, j, t-1}
$$

For both measures of LWC supply pressure (6) and (3), our methodology can establish the true effect of LWC imports if the following condition holds. Assumption 1. (Identification Restriction)

$$
\left(\epsilon_{p, j, t}-\epsilon_{p, k, t}\right) \quad \perp \quad g_{l w c, t}\left(\overline{l s}_{j}-\overline{l s}_{k}\right) .
$$


Assumption 1 requires that aggregate growth in LWCs is not the result of sector specific European demand shocks, which are systematically biased towards high or low labor-intensive sectors. Assumption 1 says that aggregate growth in LWCs has no direct effect on the difference in price changes between European sectors $j$ and $k$ other than its true impact on imports from LWCs. The orthogonality assumption does not impose that aggregate growth in LWCs is orthogonal to European demand shocks that are canceled out due to the difference-in-difference formulation.

Because $\overline{l s}_{j}-\overline{l s}_{k}$ is constant over time, the orthogonality assumption is simple: we assume that growth in LWCs is not the result of sector specific European demand shocks that are concentrated in labor intensive sectors. The orthogonality assumption fails only if all of the following three conditions hold. In Europe, there is a systematic shift of demand towards labor intensive goods (for constant prices of these goods). The demand shift induces imports from LWCs. Aggregate growth in LWCs is caused by an increase in European demand. ${ }^{3}$

\footnotetext{
${ }^{3}$ Auer and Fischer (2010) use information on U.S. consumption growth, U.S. non-LWC import demand, and U.S. production to test the orthogonality assumption, finding no evidence for this to be the case. Furthermore, even if Assumption 1 were partly violated, our results still provide a valid lower bound on the impact that imports of LWCs have on
} 


\subsection{The construction of the instrument}

The IV strategy is based on the simple observation that when LWC manufacturing output grows, their exports to Europe increase in labor intensive sectors relative to capital intensive sectors. ${ }^{4}$ Figure 1 plots average labor intensity for European industry weighted by Chinese import share, LWCs, and World from 1995 to 2008. The six LWC countries are China, India, Malaysia, Mexico, the Philippines, and Thailand. These countries are defined to be low wage because they have a high level of manufacturing exports and a GDP per capita of less than $25 \%$ of the European average. ${ }^{5}$ Based on data availability, Europe is defined by Germany, France, Italy, Sweden, and the United Kingdom. The graph highlights two stylized facts that are crucial for the IV European prices: any bias that is left would tend to an underestimation of the effect of LWC imports.

${ }^{4}$ The strategy is motivated by Heckscher-Ohlin theory and its modern extensions by Trefler (1993), Davis and Weinstein (2001), and Romalis (2004). The classical theory of trade predicts that countries should specialize in industries that intensively use relatively abundant factors.

${ }^{5}$ Using the same definition, Auer and Fischer (2010) define the following countries to be low wage for U.S. imports: China, Brazil, Indonesia, India, Malaysia, Mexico, the Philippines, Thailand, and Vietnam. See the Appendix as to how the LWC countries are selected. 
strategy. First, average labor intensity irrespective of origin is stable over the 14-year period. This feature of the data motivates the use of $\overline{l s}_{j}-\overline{l s}_{k}$. Second, there are large differences between LWC and world labor intensity. LWC exports to Europe are 20\% more labor intensive than exports from the rest of the world.

To analyze how import competition from China and other LWCs has changed over time, Figure 2 shows two scatter plots relating low-wage import competition to labor intensivity for two points in time. The upper scatter plot of Figure 2 relates the volume of European imports from the six LWCs normalized by European sales in 1996 to the sector's labor intensity. In 1996, imports were concentrated in labor-intensive industries. The lower scatter plot of Figure 2 documents that this relationship is even more pronounced in 2008. In terms of their changes, the two scatter plots of Figure 2 also imply that the increase in import competition was concentrated in labor-intensive sectors.

Based on the documented observations from Figures 1 and 2, our instrument is constructed the following way. We first generate one weight for each LWC country $i$ by averaging (imports from country $i /$ (European domestic shipments + total imports)) over (a maximum of) 110 sectors and over the 
full sample. We then construct the weighted growth of manufacturing output in the six LWCs by summing over the growth rate multiplied by the country weight. Finally, we multiply the weighted growth rate by the European labor intensity of sector $j$.

Table 1 documents the empirical motivation for our instrument. In each regression, the dependent variable is European import share for a selected country. Columns 1 to 3 serve to highlight our empirical strategy. In these three specifications, the dependent variable is the percentage point change in imports from China divided by the size of the respective sector in Europe. The size of a sector is defined as the value of domestic shipments plus the values of imports from all countries.

We first estimate a random-effects panel model in Column 1. The import share of goods imported from China is regressed on the cross product between the sector's labor share and aggregate growth of industrial production in China $\left(g_{\text {china }} \overline{l s}_{j}\right)$. We also include the two interacted components separately. Column 1 documents that when industrial output in China expands, exports to Europe grow stronger in labor intensive sectors and grow less rapidly in capital intensive sectors. The estimated coefficient for $g_{C h i n a} \overline{l s}_{j}$ is +0.006 and is highly significant. In other words, when China's industrial capacity 
grows, exports to Europe increase more in labor intensive sectors than in capital intensive sectors. Furthermore, the main effect of industrial growth is estimated to be 0.012. That is, if the annual growth of Chinese industrial output is $1 \%$, the value of exports in an industry using only capital $\left(\overline{l s}_{j}=0\right)$ increases by $0.012^{*} 0.01$, or 0.01 percentage points.

To better understand the coefficients in Column 1, consider the following exercise. In the sample covering 110 manufacturing industries, the 25th percentile of labor intensity equals about 2.5 , while the 75 th percentile is equal to 7.5. Assume that the growth rate of Chinese industrial output is $10 \%$, then the value of European imports in industry $k$ with labor intensity equal to three increases by $\left(0.006^{*} 2.5+0.012\right) * 0.1=0.27$ percentage points. In contrast, European imports in the more labor intensive industry $j$ increase by $(0.006 * 7.5+0.012) * 0.1=0.57$ percentage points. This implies that import competition from China will grow by around 0.3 percentage points more in sector $j$ than in sector $k$.

Column 2 presents the same regression as in Column 1, using fixed-effects estimation. Because the labor share is averaged over time and does therefore not vary within a sector, it is dropped from the estimation. The results are nearly identical to those of Column 1. Next, in Column 3, we also add time 
dummies to the estimation. Because the growth of Chinese industrial production is an aggregate variable, this regressor is dropped from the estimation when time dummies are introduced.

Column 3 documents that the previous results are not driven by aggregate trends (filtered out by the time dummies) or differences in sector specific trends (filtered out by fixed effects). Rather, the interaction coefficient for the growth of Chinese output multiplied by the sector's labor intensity captures the different responses that imports from sectors with different labor intensities display when China's industrial output increases.

Columns 4 to 6 repeat the same exercise with yearly and sectoral dummies for different LWC blocks: LWC-6 (i.e., China, India, Malaysia, Mexico, the Philippines and Thailand), LWC-4 (LWC-6 minus China and Mexico), LWC-10 (LWC-6 plus CEE) and low-wage CEE countries (Poland, Romania, Slovakia, and Turkey). ${ }^{6}$ The coefficients for our measure of supply driven pressures are positive and significant.

We interpret the information from Table 1 as follows: there is a systematic relation between the changes in European imports that can only be

\footnotetext{
${ }^{6}$ Again, the selection criteria for the (low-wage) CEE countries are discussed in the Appendix.
} 
rationalized by explanations of comparative advantage. When labor abundant LWCs grow, their exports increase much more in labor intensive sectors than in capital intensive sectors. To further corroborate this view, we to a falsification exercise to demonstrate the importance of labor abundance in the construction of our instrument: in Columns (8) and (9), we instrument for LWC trade with LWC growth interacted with a measure of skill intensity. The measure for skill intensity is constructed as one minus the share of non research and development workers multiplied by labor intensity. ${ }^{7}$ This measure fails to predict imports from China (see Column 8) and LWC-10.

\subsection{Data description}

We use annual trade data from Eurostat from 1995 to 2008. The classification of import data is 4-digit NACE for a maximum of 110 industrial sectors. $^{8}$

\footnotetext{
${ }^{7}$ Auer and Fischer (2010) conduct a similar exercise for Chinese exports to the United States, using skill intensity as an interaction term rather than the share of non research and development workers.

${ }^{8}$ The Statistical Classification of Economic Activities in the European Community (in French: nomenclature statistique des activities economiques dans la Communiaute europeenne), commonly referred to as NACE, is a European industry standard classification system consisting of a 6-digit code. The first four digits are the same for all European countries, whereas the fifth varies from country to country and further digits are placed by database suppliers.
} 
Western Europe in our dataset is comprised by France, Germany, Sweden, Italy, and the United Kingdom. The selection of these countries is based on data availability at the 4-digit level. European data on wages, producer prices, and productivity at the 4-digit level are also from Eurostat.

The measure of import penetration is constructed in the following manner. Consider for example the LWC-6 measure. We divide the value of total imports from the six LWCs (i.e., China, India, Malaysia Mexico, the Philippines, and Thailand) by the value of domestic shipments plus world imports. To make sure that our results are not driven by the endogenous response of European sales to European price developments, the value of domestic shipments plus world imports is averaged over the full sample. Our measure of import penetration takes the value of 0.01 in a sector where imports from the six LWCs amount to $1 \%$ of average European sales in the respective sector.

When examining changes of import penetration, we evaluate the absolute change in the level of import penetration, i.e., import penetration at time $t$ minus import penetration at $t-1$. This strategy is expedient because the response of European prices should be in relation to the increase of imports in proportion to European demand, but not in proportion to the percentage growth of imports from LWCs. Further, normalizing by sector size in Europe 
does not drop any zero-trade observations.

To measure an industry's labor intensity, we use the 1995 to 2008 average of the European labor expenditure share for each of the 110 sectors. Labor intensity is defined as the ratio of average labor expenditure divided by the average capital expenditure.

\section{LWC imports and European prices}

This section presents OLS and two-stage least squares estimates for the difference-in-difference specification of Equation (5). All estimates for European and eurozone prices are stacked regressions that include country dummies. We begin our discussion by first presenting OLS estimates of European producer prices on LWC import share. This exercise is done to highlight the bias in OLS estimation.

Panel C of Table 2 shows OLS regressions that do not support the conjecture that growing LWC imports are associated with declining European prices. The dependent variable is the percentage change of the European producer price index for each 4-digit sector. Table 2 presents results using fixed-effects panel regressions. The regression in Column 1 includes time dummies. In this specification, European prices fall by $-0.06 \%$ to a $1 \%$ above 
trend rise in LWC import share. Next, we add LWC output to the specification. Column 2 shows that the coefficient on import share collapses to 0.001 and is insignificant. A further step is to introduce wages and productivity. The coefficient of interest in this regression, shown in Column 3, is 0.015 and remains insignificant. Next, Column (4) replicates the regression of Column 1 for the three eurozone countries (i.e., France, Germany, and Italy). The coefficient on import share now is -0.029 but is still insignificant. As a last check, different dynamics are considered. In Column 5, the introduction of lagged producer prices does not alter the insignificance of import share. The same is true when lagged import share is introduced in the specification. Again, Column 6 shows that import share is negative but insignificant.

The IV regressions as opposed to the OLS regressions show that LWC exports generate a large relative price effect. European producer prices fall between $3.2 \%$ and $4.8 \%$ when LWC growth in manufacturing rises by $1 \%$ above trend. The LWC effect on European prices is statistically significant at the $1 \%$ level for all specifications.

We begin the discussion of the IV results with the first-stage regressions. These regressions are displayed in Panel A of Table 2. In each specification, the instrument passes several tests of weak instruments. The Cragg-Donald 
statistics and the associated Stock-Yogo statistic, as well as the F-statistic from the first-stage regressions reveal that the criticism of weak instruments is not an issue. The same panel also shows that the variable of interest, labor intensity multiplied by the change in LWC industrial output, is significant at the $1 \%$ level.

The second-stage IV regressions show that the relative price effect is stable in the different specifications. These are presented in Panel B. Column 1 shows that the relative price effect is -3.5 and highly significant in the baseline regression with time dummies. This point estimate means that a $1 \%$ increase in LWC import share is associated with a 3.5\% fall in European producer prices. The addition of manufacturing output to the baseline regression shown in Column 2 does not change the -3.5 estimate. The next regression in Column 3 adds sectoral productivity and wages to the specification. Although these variables may be endogenous to LWC import share, the coefficient on LWC import share jumps to $-4.8 \%$. This increase in the estimated coefficient is possibly explained by the restricted sample (7010 observations in Column 1 versus 5620 observations in Column 3). Next, the eurozone regression presented in Column 4 shows a slightly lower price effect at -3.2. The last two specifications in Columns 5 and 6 that control for 
dynamics do not alter the baseline estimate.

When we observe that the market share of LWC imports grows, this could stem from either more goods being imported at constant prices (the channel we want to isolate), or alternatively, the same quantity being imported at higher prices. To make sure that we study the first effect, a first robustness test uses physical import volumes (measured in mostly in kilos) in the first-stage regressions instead of import values (measured in euros). Also the measure of physical import volumes is normalized by the size of the market, which is measured in the same physical quantity as is the import volume. Estimates for European prices and their corresponding specifications as in Table 2 are shown in Table 3. In terms of the strength of the instrument, the first-stage regressions show higher F-tests than the regressions with import values. The relative price effect remains highly significant but is now estimated to be around of $-2 \%$ for Europe and $-1.5 \%$ for the euro zone.

\section{LWC import competition from Asia and Emerging Europe: Disentangling the effect on inflation}

In this section, we show that the IV strategy can be used in a bilateral setting to answer the question whether Chinese exports lower European producer 
prices. ${ }^{9}$ As a further step we focus on how diffuse LWC import competition is in Europe and examine which European regions are influenced the most. As a last step, we focus on a special group of low-wage countries from CEE.

\subsection{How large is the China effect for Europe?}

The China question for Europe is of interest because the European Commission currently defines China to be the single most important challenge for EU trade policy. China is the EU's biggest source of imports. More importantly, the results for the bilateral setting show that the Chinese-American debate on inflation extends to the European continent.

To highlight the strength of our instrument in a bilateral setting, we re-run the regressions for LWCs in Tables 2 and 3 but now separately for China. Table 4 presents OLS and IV estimates of Chinese import share on European producer prices. The OLS results show that the coefficient for the change in import value (measured in euros) is negative and significant for different specifications. Column 1 of Panel C shows a significant coefficient of -0.09 in the panel regressions with annual dummies. Column 2 shows

\footnotetext{
${ }^{9}$ The study by Chen et al. (2009) relies on instruments (i.e., distance, volume, and exchange rates) that work only in a multilateral setting and thus cannot shed light on the China question posed by Kamin et al. (2006) and Wheeler (2008).
} 
the regression that adds Chinese manufacturing. The coefficient on import share now falls to -0.032 and is insignificant. Further, Column 3 shows an extended regression that includes productivity and wages. The coefficient of interest falls further to -0.016 and is significant only at the $10 \%$ level. Next, Column 4 replicates the estimates for Column 1 for the major eurozone countries: France, Germany, and Italy. Here, the results are similar to those for Column 1 with the five European countries. The last two specifications in Columns 5 and 6 consider different dynamics of the specification in Column 1. The introduction of lagged producer prices or lagged import share mitigates slightly the estimate for Chinese import share from -0.09 (see Column 1) to -0.07 .

Next, IV estimates show that the price effect is much larger than the OLS estimates. The IV estimates are recorded in Panel B and the accompanying first-stage regressions for the instrument equation are presented in Panel A. Depending on the specification, the highly significant coefficient on Chinese import share lies between -3.8 and -6.8 . These estimates are considerably higher than for the LWC-6 estimates in Table 2, which were between -3.2 and -4.8. Our preferred specification of Column 1 yields a price effect of -5.1. Auer and Fischer (2010) find that the same effect for the United States is 
only $2.5 \%$ using 6-digit NIC data. However, it should be noted that direct comparisons are difficult, because different concordance assumptions are used in the NIC and NACE classifications.

To control for valuation effects through the exchange rate on producer prices, we also show estimates for Chinese import volume measured in kilogram. For completeness, OLS and IV estimates are shown in Table 5. Jumping to the IV regressions of Panel B, the estimates show that the "China effect" on European Prices lies between -1.9 to -2.7 . These highly significant coefficient estimates for Chinese imports have a stronger effect on European prices than do the estimates using LWC-6. The difference is in the order of 0.5 percentage points. This result is not surprising given the fact that half of the total LWC-10 import share stems from China, and that Chinese goods are probably the cheapest of all the imports hence also exerting the highest pro-competitive pressure on European markets.

\subsection{Bilateral estimates for individual European countries}

Until now we treated Europe as a single regional block. Next, we ask whether LWC exports impact producer prices differently across European countries. A priori, we do not expect LWC import competition to be homogeneous across countries or regions. Differences in market size, trade linkages, and 
dynamics expose countries to different levels of LWC import competition.

Table 6 records the regression estimates of LWC import competition on Germany, France, Sweden, Italy, and the United Kingdom. Panel B displays the second-stage relation between changes in import values in Columns 1 to 5 and import volumes in Columns 6 to 10. Panel A presents the equivalent information from the first-stage regression. The regressions are similar in specification to those presented in Column 1 of Tables 2 and 3 . The regressors are LWC-6 import share and time dummies.

The regression results show that LWC import competition is wide-spread, yet the size of the impact varies between European countries. There is strong evidence of LWC import competition in Germany, Sweden, and the United Kingdom. The coefficient estimates for import share are significant for all countries except for Italy in the regressions using import values (i.e., Columns 1 to 5) and are significant for Germany, Sweden, and the United Kingdom in the regressions using import volume. Further, the coefficient estimates for import values and import volumes show that the LWC penetration effect for prices is strongest for the United Kingdom and Sweden, followed by Germany and France. When LWC exporters capture 1\% of British market share, producer prices decrease by $-3.8 \%$ in the regression using import volumes. In the 
same regression for Sweden the price effect is $-2.6 \%$, whereas for Germany it is only $-1.2 \%$.

In contrast, the estimates for Italy suffer in that neither of the first-stage estimates are significant. Further, it should be noted that the low degrees of freedom and data quality may partially explain the poor performance for Italy. This finding is also in accordance with Bugamelli et al. (2010), who find a significant (since they are using micro data at the establishment level), but only small effect of Chinese import competition on Italian prices when using an instrumentation strategy combining elements of Bernard et al. (2006) and Auer and Fischer (2010).

\subsection{Central and Eastern Europe's impact on European prices}

What is the impact of the increasing integration between our five import markets and CEE on producer prices? The fall of the Berlin Wall unleashed a large pool of low-wage workers that quickly converged to European standards. Our definition of a low-wage country assumes a high share of manufactured exports and that a nation's average GDP per capita is less than $25 \%$ of the average GDP per capita for Italy, Germany, France, Sweden and the United Kingdom. This LWC definition includes Poland, Romania, Slovakia, and Turkey. The results in the previous sections show a strong impact from 
LWCs primarily from Asia. Does CEE import competition also influence European prices?

The empirical evidence for CEE import competition is limited at best. A first hurdle lies with the low power of the instrument when applied to this group of countries: labor intensity alone cannot explain marginal exports to Western Europe. Table 7 shows first-stage regressions using import volume for the four low-wage CEE countries plus Russia, the Czech Republic, and Hungary. All estimations include fixed effects by sector and year dummies. Although Russia, the Czech Republic, and Hungary do not fulfill our LWC definition, they are used as controls (since we slightly modify our instrumentation strategy). The regression in Panel B thus use the same instrument of Tables 2 to 6 that multiplies European labor intensity by Eastern European manufacturing: the instrument of Auer and Fischer (2010) is not significant for the CEE countries.

To refine our instrumentation strategy, we instead use Equation (6) where we weigh the instrument proposed in (3) by the lagged import share of the CEE exporters in each Western European importer, i.e., we adjust our instrument to correct for the small market share of low-wage CEE countries. Panel A of Table 7 displays the first-stage relation between changes of import 
volumes from the individual CEE countries and the CEE countries' sectoral weight multiplied by the change in the CEE countries' manufacturing output. ${ }^{10}$ Our adjusted instrument is significant for three of the four low-wage countries, while our three non low-wage CEE countries that act as controls are insignificant.

The next step in the IV analysis shows only limited evidence of low-wage CEE import competition for European producer prices. The single country effect is lower than the estimates found in Tables 2 to 6 and is significant only for a single country. Table 8 presents IV regressions only for the three low-wage CEE countries (Romania, Poland, and Turkey) that passed the first-stage hurdle using our adjusted instrument in Panel A of Table 7. The regressions show only a significant result for Romania. When Romanian exporters capture 1\% of European market share, producer prices decrease about $1.0 \%$. In contrast, no such effect is present for Poland and Turkey.

Several factors could explain the non import competition result for lowwage CEE countries versus the strong results for the six LWCs. A first

\footnotetext{
${ }^{10}$ The changes of import volumes are defined as the year-on-year absolute change in (LWC import volume/European industry size), where the industry size is defined as the 1995-2008 average value of European domestic production plus world imports.
} 
issue is that our low-wage CEE countries are only border line low-wage. If we alter our definition from $25 \%$ to $20 \%$ of European per capita GDP, Poland and Slovakia fall out. As expected, Romania, the only "true" lowwage country is also the one where we do find a significant effect. A related issue is the CEE labor market does not match the Chinese labor pool. China possesses a vast reservoir of labor that mitigates wage growth in the dynamic coastal regions. Instead, CEE wages and productivity have risen rapidly, converging to European levels. Further, Auer and Fischer (2008) show that Chinese output in low-skilled products is wide ranging. In contrast, CEE manufacturing tends to be sector specific and thus does not have the same breadth as Chinese goods to impact European producer prices.

\section{Conclusions}

This paper investigates how imports from LWCs influence European producer prices. The results show that the IV strategy of Auer and Fischer (2010) has far reaching applications beyond the U.S. case. This IV strategy relies on the observation that when LWCs grow, their exports increase much more in labor intensive sectors than in capital intensive sectors. We therefore instrument for trade flows using the interaction between growth of 
LWC manufacturing output and sectoral labor share. To filter out aggregate correlations and sector specific trends, we use a difference-in-difference specification that exploits only how sectoral differences in trade flows affect sectoral differences in price changes above trend. Although aggregate growth may be endogenous to global demand, the difference in how various sectors are affected by growth can be exploited to identify the causal effects of trade.

In a panel covering 110 (4-digit) NACE industries from 1995 to 2008, the results show that trade with LWCs has a strong impact on European producer prices. More specifically, the findings document that the traditional LWCs such as China generate a larger price impact than the newly integrating EU countries such as Poland and Romania that also satisfy our definition of low-wage country. When exporters from traditional LWCs capture $1 \%$ of European market share, producer prices decrease about $2 \%$. In contrast, no such effect is present for import competition from CEE countries. 


\section{References}

Auer, R. and A. M. Fischer, 2010. The effect of low-wage import competition on U.S. inflationary pressure, Journal of Monetary Economics 57(4), 491503.

Bernard, A. B., J. B. Jensen, and P. K. Schott, 2006 . Survival of the best fit: exposure to low-wage countries and the (uneven) growth of U.S. manufacturing plants. Journal of International Economics 68(1), 219-237.

Borio, C., and A. Filardo, 2007. Globalisation and inflation: new crosscountry evidence on the global determinants of domestic inflation, BIS Working Paper 227. Basel: Bank for International Settlements, May.

Bugamelli, M., S. Fabiani, and E. Sette, 2010. The pro-competitive effect of imports from China: an analysis of firm level price data, Temi di discussione 737, Bank of Italy.

Carney, M., 2008. The implications of globalization for the economy and public policy, Remarks by the Governor of the Bank of Canada to the British Columbia Chamber of Commerce and Business Council of British Columbia, Vancouver, British Columbia, 18 February 2008.

Chen, N., J. Imbs, and A. Scott, 2009. The dynamics of trade and competition, Journal of International Economics 77(1), 50-62.

Davis, D. R. and D. E. Weinstein, 2001. An account of global factor trade, American Economic Review 91(5), 1423-1453.

De Gregorio, J., 2008. The tensions of the world economy, Economic Policy Paper 27, Bank of Chile.

Gamber, E. and J. H. Hung, 2001. Has the rise in globalization reduced U.S. inflation in the 1990s, Economic Inquiry 39(1), 58-73.

Glatzer, E., E. Gnan, and M. T. Valderrama, 2006. Globalization, import prices and producers in Austria, monetary policy and the economy, Austrian National Bank, No. 3, 24-43.

Ihrig, J., S. B. Kamin, D. Lindner, and J. Marquez, 2007. Some simple tests of the globalization and inflation hypothesis, International Finance 
Discussion Papers 891. Washington: Board of Governors of the Federal Reserve System, April.

Kamin, S. B., M. Marazzi, and J. W. Schindler, 2008. The impact of Chinese exports on global import prices, Review of International Economics, 14(2), 179-201.

Melitz, M. J. and G. I. P. Ottaviano, 2008. Market size, trade an productivity, Review of Economic Studies 75(1), 295-316.

Mishkin, F. S., 2007. Globalization, macroeconomic performance, and monetary policy, Held at the Domestic Prices in an Integrated World Economy Conference, Board of Governors of the Federal Reserve System, Washington, D.C.

Pain, N., I. Koske, and M. Sollie, 2008. Globalisation and inflation in the OECD economies, OECD Economics Department Working Paper No. 524. Paris: Organisation for Economic Co-operation and Development, November.

Romalis, J., 2004. Factor proportions and the structure of commodity trade, American Economic Review 94(1), 67-97.

Tootell, G. M. B., 1998. Globalization and U.S. inflation, New England Economic Review, Federal Reserve Bank of Boston, July, 21-33.

Trefler, D., 1993. International factor price differences: Leontief was right, Journal of Political Economy 101(4), 961-987.

Trichet, J. C., 2008. Globalisation, inflation and ECB monetary policy, Speech held at the Barcelona Graduate School of Economics, Barcelona, 14 February 2008.

Wheeler, T., 2008. Has trade with China affected UK inflation?, External MPC Unit Discussion Paper No 22, Bank of England.

World Economic Outlook, 2008. How has globalization affected inflation?, Chapter 3, 97-134. 


\section{Appendix: Selection Criteria for LWCs and Data Sources}

\section{Selection criteria for low wage countries}

We define a country to be low wage if a nation's average GDP per capita (averages from 1995-2008) is less than 25\% of the average GDP per capita (in current US dollars) for Italy, Germany, France, Sweden and the United Kingdom (average GDP for the five countries between 1995 to 2008). There are 137 countries with a per capita GDP of less than $25 \%$ of average European GDP per capita. However, there are many countries among them that account for only a small fraction of total European imports. We drop all countries whose exports account for less than $5 \%$ of European imports. This leaves us with 24 economies.

We next account only for countries in which the share of manufactured exports (in percent of total merchandizing exports) is higher than $70 \%$. The last criterion leaves us with 10 economies, which are China, India, Malaysia, Mexico, Philippines, Poland, Romania, Slovak Republic, Thailand, and Turkey. These countries account for $12.4 \%$ of total mean imports of Italy, France, Germany, Sweden and United Kingdom. China contributes most to this share. In 2008, almost 50\% of this LWC import share is accounted for by China. Poland with $18 \%$ and Turkey with about $9 \%$ are the second and third largest contributors. All other countries account for around 5\% or less of total LWC imports.

In the analysis, we first focus on the following six countries China, India, Malaysia, Mexico, the Philippines and Thailand, and define them as (traditional) LWC. Separately, we consider the impact of CEE countries: Poland, Romania, the Slovak Republic, and Turkey.

How would altering the sample criterion affect our sample? Changing the cut-off of a low-wage country to $20 \%$ of US GDP per capita excludes Mexico, Poland, and the Slovak Republic. Altering the share of manufactured exports in total merchandizing exports to $75 \%$ would exclude India with a share of $72.9 \%$. Lowering the threshold to $65 \%$ would include Ukraine. By lowering the threshold to 50\%, we would include Brazil and South Africa. Finally, by lowering the export threshold value of $5 \%$ of European imports to only $1 \%$ of European imports, we would include Bangladesh, Pakistan, Sri Lanka and Tunisia.

\section{Data sources}

a) Trade data

Data on external (bilateral) trade are from Eurostat. Detailed 8-digit product level data (classified in CN8) are available from 1988 to 2008 for various European countries and country groups. ${ }^{11}$ The analysis is restricted to imports from the following partner countries: Canada, Mexico, Brazil,

\footnotetext{
${ }^{11}$ These countries are France, Netherlands, Germany, Italy, United Kingdom, Ireland, Denmark, Greece, Portugal, Spain, Belgium, Luxembourg, Sweden, Finland, Belg.-
} 
India, Thailand, Vietnam, Indonesia, Malaysia, Philippines, China, Japan, Bulgaria, Moldova, Romania, Russia, Slovakia, Ukraine, Hungary, Poland, Czech Republic, and Belarus. Eurostat's external trade statistics provides information about the import value (measured in 1000 ECUs), and import volume (measured in tons).

To match the external trade data with the other data sources classified at the NACE economic activity level, it is necessary to convert the product-level data to the NACE classification. For this exercise, the ad-hoc conversion tables created by Eurostat Unit G3 "International trade-Production" are used. $^{12}$ This concordance table allows a conversion from CN8 to CPA (4digit statistical classification of products by activity). ${ }^{13}$ The correspondences are created from a multiple $(\mathrm{CN})$ to a single (CPA classification) basis. The product-level data by CPA are summed to construct an aggregate measure for the import value and volume by $\mathrm{CPA} / \mathrm{NACE}$.

To construct the instrument, sectoral values of world imports and the sectoral domestic production are needed. These are then averaged over the sample period. The sectoral domestic production and aggregate import values are taken from the PRODCOM database of Eurostat. PRODCOM is an 8-digit product-level classification of industrial production data. The first 4 digits correspond to the NACE (Rev. 1.1) classification. For the import and production values, the corresponding NACE-level measure can be obtained by simply aggregating the values over the different products within each NACE class. For the corresponding quantities, the aggregation is not straightforward: As different products within one NACE-class are measured in different units (such as $\mathrm{kg}$, litres, pieces etc.). In a first step all units are converted into $\mathrm{kg}$ to match the trade data (which is classified in 1000kg). To convert all units to $\mathrm{kg}$, the mean value per $\mathrm{kg}$ within each NACE-class are used to approximate the quantities of those products which are not in $\mathrm{kg}$. In cases where no product per NACE class is classified in $\mathrm{kg}$, they are treated as missing values.

b) Price data

The price data are from Eurostat. The industry producer price index for the domestic market are used. These data are classified as NACE Rev. 2 and range from 1975 to 2008. However, for most of the countries, data is available only from 1990 or even later, especially at the most detailed 4-digit level. Furthermore, 4-digit level is not available for all divisions or groups.

Luxembourg, Austria, Malta, Estonia, Latvia, Lithuania, Poland, Czech Republic, Slovakia, Hungary, Romania, Bulgaria, Slovenia Cyprus, the EU, EU15 and EU25.

${ }^{12}$ See http ://ec.europa.eu/eurostat/ramon/other ${ }_{d}$ ocuments/index.cfm?TargetUrl $=$ $D S P_{O} T H E R_{D} O C_{D} T L$

${ }^{13}$ The CPA classification corresponds to the NACE Rev. 1.1 classification. 
The NACE Rev. 2 data has to be converted into NACE Rev. 1.1 to match it with the other data. For this, the correspondences provided by Eurostat are used. For those classes without a unique correspondence, the classes are chosen which matched best among the competing classes. For example, the class DK29.13 (Manufacture of taps and valves) in NACE Rev. 1.1 corresponds to both, the class C28.14 (Manufacture of other taps and valves) and C33.12 (Repair of machinery). As C28.14 corresponds better to the target code, C28.14 is used as the source code.

c) Other variables

To construct labor intensity, data from the structural business statistics (sbs), downloadable from Eurostat, are used. The structural business statistics comprise information such as different measures of value added, turnover, the number of employees, number of hours, $R \& D$ expenditure, labor productivity, personnel costs, gross investment in tangible goods (such as buildings and structures, land, machinery and equipment), or energy expenditures. These variables are disaggregated at 4-digit NACE Rev. 1.1 for 1995 to 2007 and at 2- or 3-digit level for 1985 to 1995.

Sectoral labor intensity is constructed as the average (over time and countries) of personnel costs divided by the average gross investment in tangibles, which serves as a proxy for capital expenditures.

Finally, data on manufacturing growth in the LWC countries are obtained from Datastream [CN, IN, MY, TH, JP, VN], IFS [PH, MX] or the OECD Main Economic Indicators [CA, BR, ID, CN]. 
Figure 1: Average European labor intensity by import origin (1995-2008)

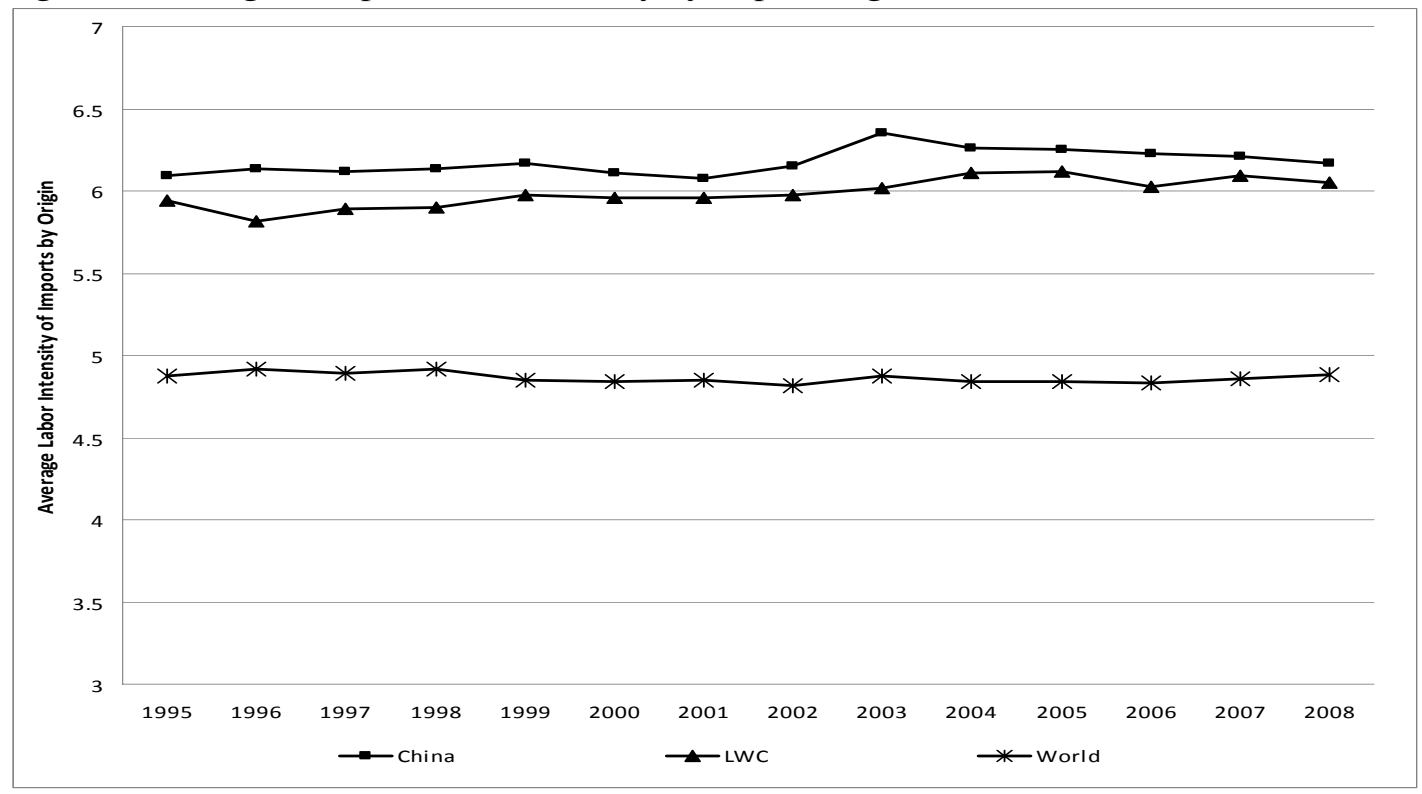

Notes: Europe is France, Germany, Italy, Sweden, and the United Kingdom. LWC imports are from China, India, Malaysia, Mexico, the Philippines, Thailand. Data source are Eurostat (4-digit) 110 NACE industries from 1995- 2008 
Figure 2: Labor intensive sectors and LWC import share

LWC import share 1996

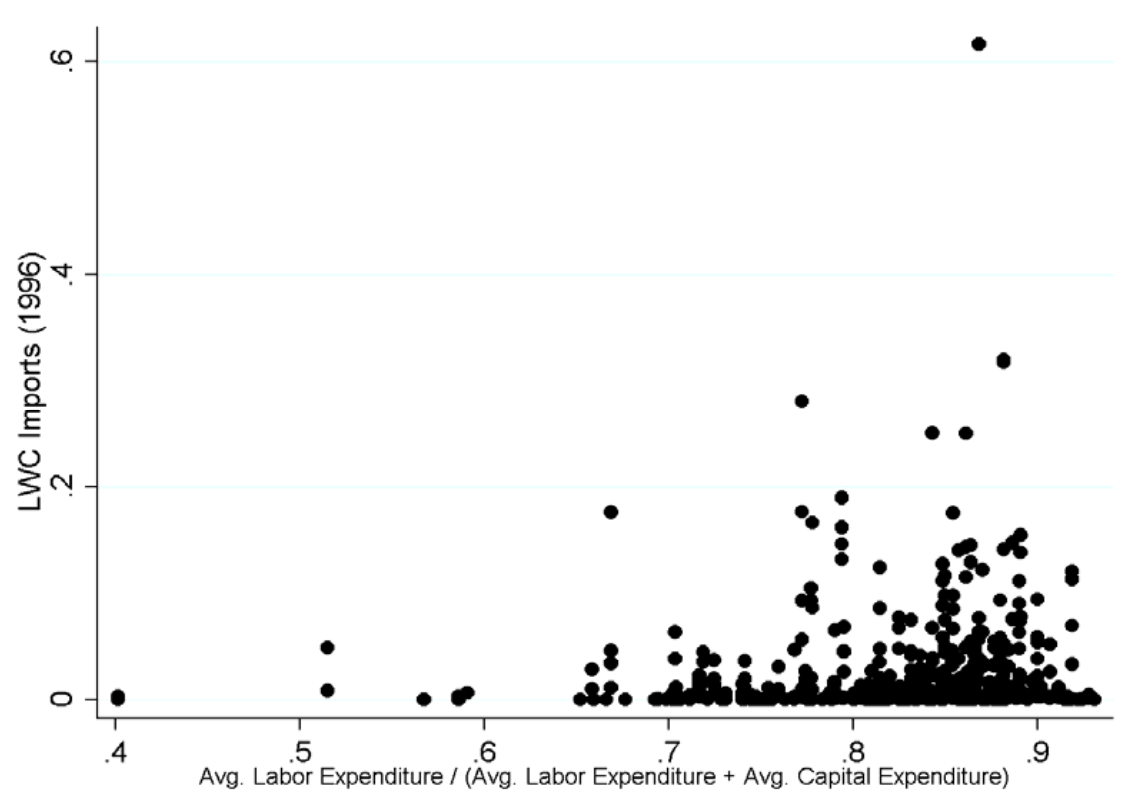

LWC import share 2008

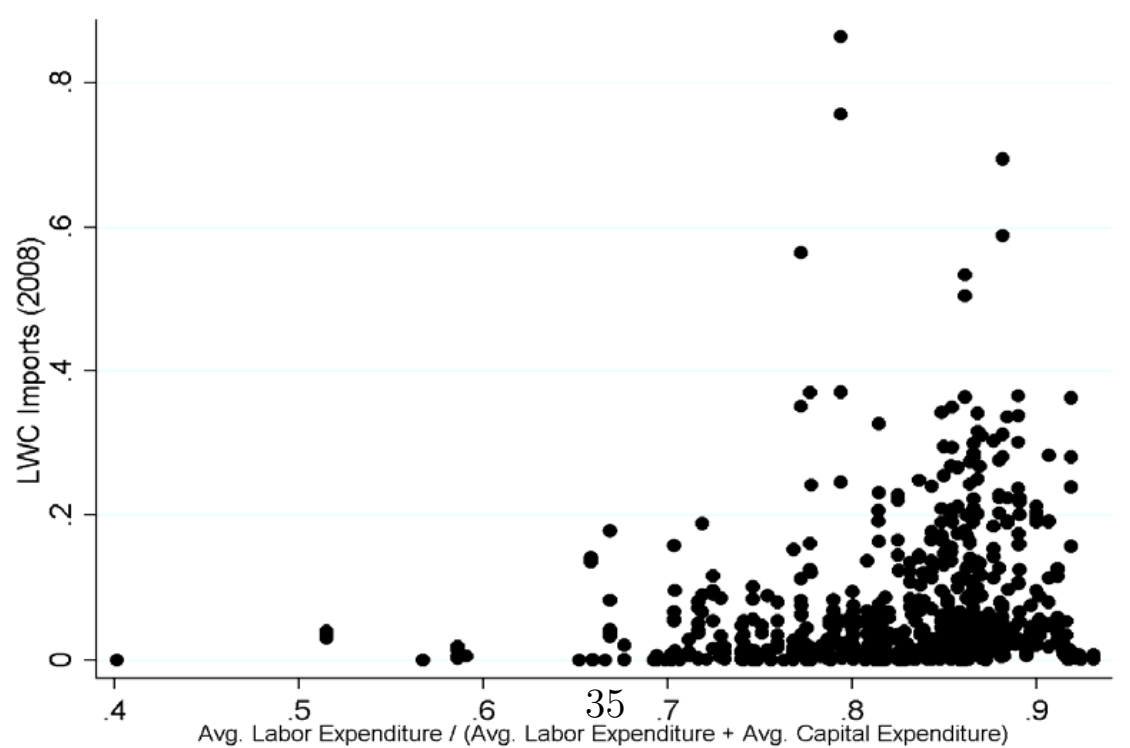

Notes: Europe is France, Germany, Italy, Sweden, and the United Kingdom. LWC imports are from China, India, Malaysia, Mexico, the Philippines, Thailand. Data source are Eurostat (4-digit) 110 NACE industry sectors. 


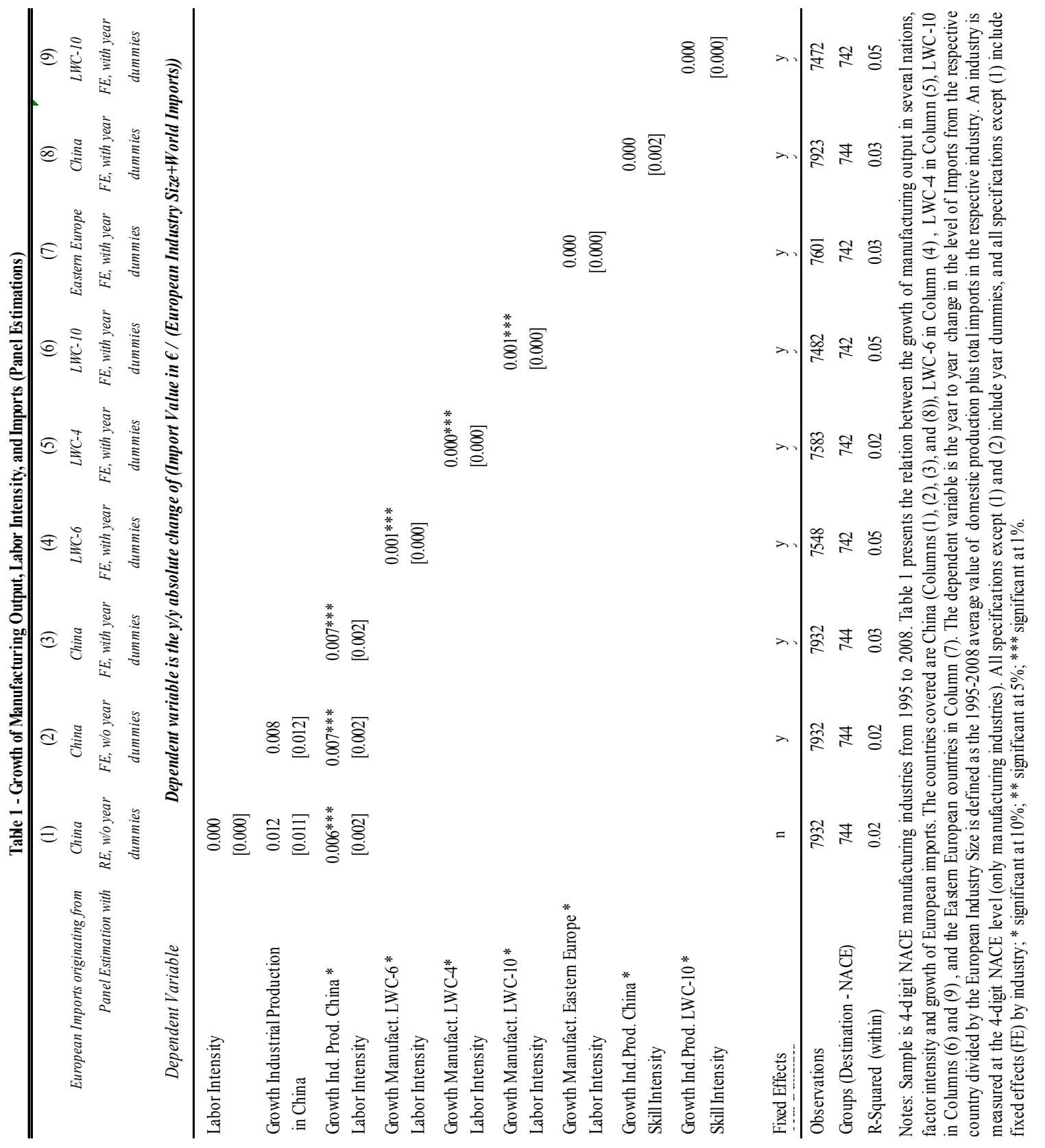


Table 2 - LWC Import Value (in $€$ ) and European ${ }^{1}$ Prices: OLS and IV Results (Fixed Effects Panel Estimations)

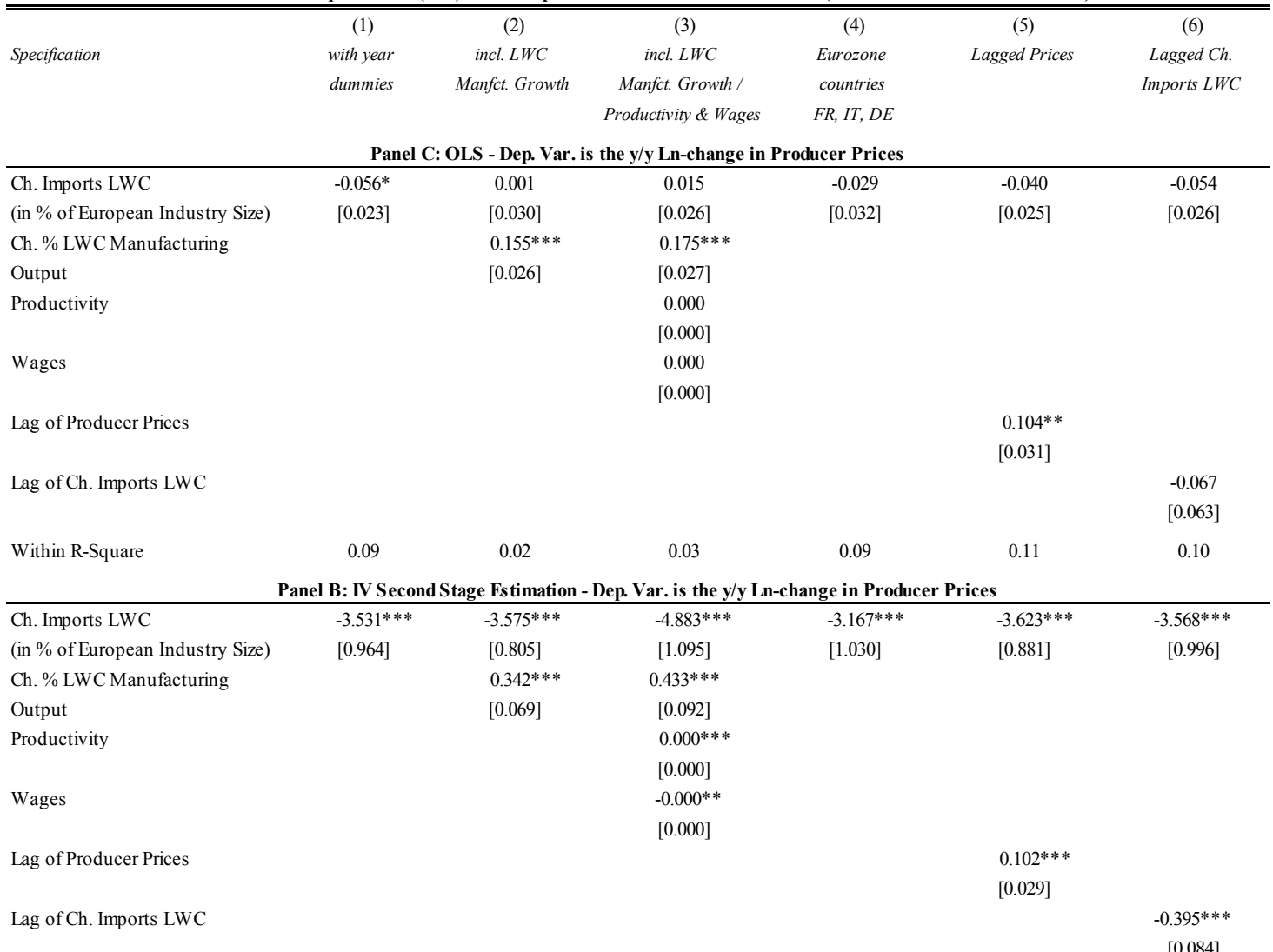

[0.084]

Panel A: IV First Stage Estimation - Dep. Var. is the $y / y$ change in (LWC Import Value in $€$ / European ${ }^{1}$ Industry Size)

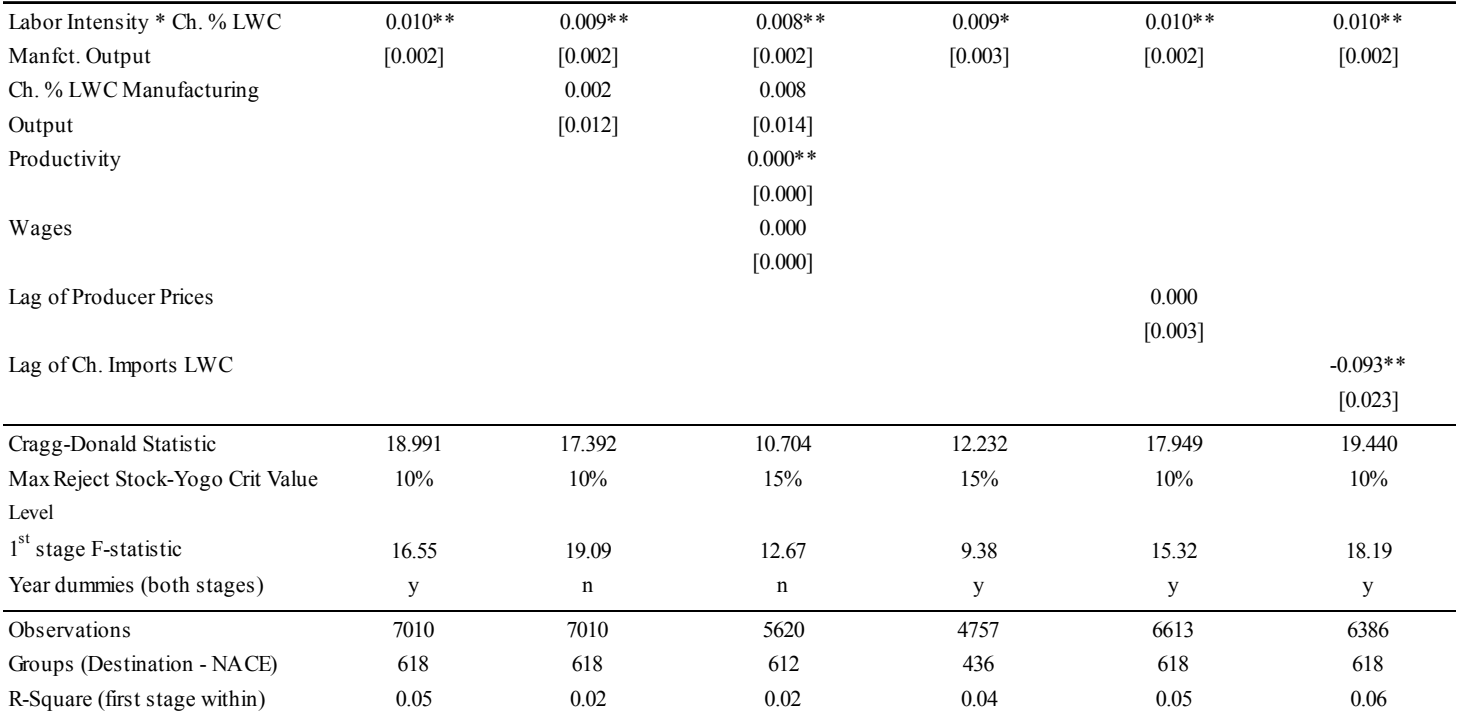

Notes: ${ }^{1}$ Europe is France, Germany, Italy, United Kingdom, and Sweden. Panel C of Table 2 shows the OLS relation between changes of import values in $€$ from six LWCs and European producer prices. Panel B displays two-stage least squares estimations. The dependent variable is the annual change in the logarithm of the producer price at the four-digit NACE (Rev. 1.1) levelffonly manufacturing industries). "Ch. Imports LWC" is defined as the y/y absolute change in (LWC import value in €/European industry size). The industry size is defined as the 1995-2008 average value of European domestic production plus world imports. In columns 2 and 3, "Ch. \% LWC Manufacturing Output" is the weighted average growth rate of manufacturing output in the six LWCs. Productivity is the wage adjusted labour productivity and wages capture wages and salaries. Column 4 captures only countries in the Eurozone, i.e. France, Germany and Italy. Column 5 includes lagged producer price changes and column 6 incorporates lagged changes of LWC import values. In Panel A the first-stage relation is displayed. The instrument is the sector's labor intensity times " $\mathrm{Ch}$. \% LWC Manufacturing Output". All estimations include fixed effects by sector. Clustered standard errors (by country) reported in brackets; $*$ significant at $10 \% ; *$ significant at $5 \%$; ** significant at $1 \%$. 
Table 3 - LWC Import Volume (in kilograms) and European ${ }^{1}$ Prices: OLS and IV Results (Fixed Effects Panel Estimations)

\begin{tabular}{ll}
\hline \hline Specification & with \\
& dum \\
& \\
\hline Ch. Imports LWC & \\
(in \% of European Industry Size) \\
Ch. \% LWC Manufacturing \\
Output \\
Productivity \\
Wages
\end{tabular}

$\begin{array}{ccc}\text { (1) } & (2) & (3) \\ \text { with year } & \text { incl. } \text { LWC } & \text { incl. } \text { LWC } \\ \text { dummies } & \text { Manfct. Growth } & \text { Manfct. Growth/ } \\ & & \text { Productivity \& Wages }\end{array}$

(4)

Eurozone

(5)

(6)

$-0.078 *-0.097 * \quad-083 * *$

$[0.035] \quad[0.043] \quad[0.028] \quad[0.063]$

$-0.061-0.076^{*}$

$0.206 * * * \quad 0.224 * * *$

$[0.028] \quad[0.029]$

$[0.029]$
0.000

[0.000]

0.000

[0.000]

Lag of Producer Prices

$0.073 * *$

Lag of Ch. Imports LWC

$[0.025]$

Within R-Square

0.11

0.02

0.05

0.11

$-0.038^{* *}$

[0.009]

Panel B: IV Second Stage Estimation - Dep. Var. is the $\mathbf{y} / \mathbf{y}$ Ln-change in Producer Prices

\begin{tabular}{llll}
\hline Ch. Imports LWC & $-1.992^{* * *}$ & $-1.922^{* * *}$ & $-2.326^{* * *}$ \\
(in \% of European Industry Size) & {$[0.638]$} & {$[0.534]$} & {$[0.746]$} \\
Ch. \% LWC Manufacturing & & $0.307 * * *$ & $0.348^{* * *}$ \\
Output & & {$[0.051]$} & {$[0.057]$} \\
Productivity & & $0.000^{* *}$ \\
& & {$[0.000]$} \\
Wages & & $0.000^{* *}$ \\
& & {$[0.000]$}
\end{tabular}

Lag of Producer Prices

$0.000]$

Lag of Ch. Imports LWC

$0.074 * * *$

[0.023]

$-0.254 * * *$

[0.073]

Panel A: IV First Stage Estimation - Dep. Var. is the y/y change in (LWC Import Volume in kilograms/ European ${ }^{1}$ Industry Size)

\begin{tabular}{|c|c|c|c|c|c|c|}
\hline Labor Intensity * Ch. \% LWC & $0.020 * * *$ & $0.021 * * *$ & $0.021 * *$ & $0.021 *$ & $0.020 * * *$ & $0.022 * * *$ \\
\hline Manfct. Output & {$[0.004]$} & {$[0.004]$} & {$[0.005]$} & {$[0.007]$} & {$[0.004]$} & {$[0.004]$} \\
\hline Ch. \% LWC Manufacturing & & $-0.045^{*}$ & $-0.048^{*}$ & & & \\
\hline Output & & {$[0.017]$} & {$[0.018]$} & & & \\
\hline \multirow[t]{2}{*}{ Productivity } & & & 0.000 & & & \\
\hline & & & {$[0.000]$} & & & \\
\hline \multirow[t]{2}{*}{ Wages } & & & 0.000 & & & \\
\hline & & & {$[0.000]$} & & & \\
\hline \multirow[t]{2}{*}{ Lag of Producer Prices } & & & & & 0.001 & \\
\hline & & & & & {$[0.003]$} & \\
\hline \multirow[t]{2}{*}{ Lag of Ch. Imports LWC } & & & & & & $-0.114 * * *$ \\
\hline & & & & & & {$[0.007]$} \\
\hline Cragg-Donald Statistic & 44.089 & 44.180 & 38.093 & 34.506 & 40.705 & 48.839 \\
\hline Max Reject Stock-Yogo Crit Value & $10 \%$ & $10 \%$ & $10 \%$ & $10 \%$ & $10 \%$ & $10 \%$ \\
\hline \multicolumn{7}{|l|}{ Level } \\
\hline $1^{\text {st }}$ stage F-statistic & 26.32 & 25.12 & 15.87 & 9.057 & 23.06 & 26.91 \\
\hline Year dummies (both stages) & $\mathrm{y}$ & $\mathrm{n}$ & $\mathrm{n}$ & $\mathrm{y}$ & $\mathrm{y}$ & $\mathrm{y}$ \\
\hline Observations & 4908 & 4908 & 3935 & 3329 & 4633 & 4468 \\
\hline Groups (Destination - NACE) & 434 & 434 & 429 & 305 & 434 & 434 \\
\hline R-Square (first stage within) & 0.05 & 0.0338 & 0.03 & 0.06 & 0.05 & 0.10 \\
\hline
\end{tabular}

Notes: ${ }^{1}$ Europe is France, Germany, Italy, United Kingdom, and Sweden. Panel C of Table 3 shows the OLS relation between changes of import volume (in kilograms) from six LWCs and European producer prices. Panel B disp lays two-stage least squares estimations. The dependent variable is the annual change in the logarithm of the producer price at the four-digit NACE (Rev. 1.1) level (only manufacturing industries). "Ch. Imports LWC" is defined as the $\mathrm{y} / \mathrm{y}$ absolute change in (LWC import volume in $\mathrm{kg}$ /European industry size). The industry size is defined as the 1995-2008 average value of European domestic production plus world imports. In columns 2 and 3, "Ch. \% LWC Manufacturing Output" is the weighted average growth rate of manufacturing output in the six LWCs. Productivity is the wage adjusted labour productivity and wages capture wages and salaries. Column 4 captures only countries in the Eurozone, i.e. France, Germany and Italy. Column 5 includes lagged producer price changes and column 6 incorpora tes lagged changes of LWC import volumes. In Panel A the first-stage relation is displayed. The instrument is the sector's labor intensity times "Ch. \% LWC Manufacturing Output". All estimations include fixed effects by sector. Clustered standard errors (by country) reported in brackets; * significant at $10 \% ; * *$ significant at $5 \% ; * * *$ significant at $1 \%$. 
Table 4 - China Import Value (in $€$ ) and European ${ }^{1}$ Prices: OLS and IV Results (Fixed Effects Panel Estimations)

\begin{tabular}{|c|c|c|c|c|c|c|}
\hline Specification & $\begin{array}{c}\text { (1) } \\
\text { with year } \\
\text { dummies }\end{array}$ & $\begin{array}{c}\text { (2) } \\
\text { incl. China } \\
\text { Ind. Growth }\end{array}$ & $\begin{array}{c}\text { (3) } \\
\text { incl. China } \\
\text { Ind. Growth/ } \\
\text { Productivity \& Wages }\end{array}$ & $\begin{array}{c}\text { (4) } \\
\text { Eurozone } \\
\text { countries } \\
F R, I T, D E\end{array}$ & $\begin{array}{c}\text { (5) } \\
\text { Lagged Prices }\end{array}$ & $\begin{array}{c}\text { (6) } \\
\text { Lagged Ch. } \\
\text { Imports LWC }\end{array}$ \\
\hline \multicolumn{7}{|c|}{ Panel C: OLS - Dep. Var. is the $y / y$ Ln-change in Producer Prices } \\
\hline Ch. Imports China & $-0.092 * * *$ & $-0.032 *$ & $-0.016^{* *}$ & $-0.085^{* * *}$ & $-0.073^{* * *}$ & $-0.078 * * *$ \\
\hline (in \% of European Industry Size) & {$[0.019]$} & {$[0.016]$} & {$[0.007]$} & {$[0.026]$} & {$[0.014]$} & {$[0.015]$} \\
\hline Ch. \% China Manufacturing & & $0.184 * * *$ & $0.209^{* * *}$ & & & \\
\hline Output & & {$[0.032]$} & {$[0.038]$} & & & \\
\hline \multirow[t]{2}{*}{ Productivity } & & & 0.000 & & & \\
\hline & & & {$[0.000]$} & & & \\
\hline \multirow[t]{2}{*}{ Wages } & & & 0.000 & & & \\
\hline & & & {$[0.000]$} & & & \\
\hline \multirow[t]{2}{*}{ Lag of Producer Prices } & & & & & $0.104^{* *}$ & \\
\hline & & & & & {$[0.031]$} & \\
\hline
\end{tabular}

Lag of Ch. Imports China

$\begin{array}{llllll}0.09 & 0.02 & 0.04 & 0.09 & 0.11 & 0.10\end{array}$

Within R-Square

0.09

0.02

0.04

0.09

$[0.078]$

Panel B: IV Second Stage Estimation - Dep. Var. is the $\mathbf{y} / \mathbf{y}$ Ln-change in Producer Prices

\begin{tabular}{lcccccc}
\hline Ch. Imports China & $-5.101 * * *$ & $-4.840^{* * *}$ & $-6.728^{* * *}$ & $-3.864 * * *$ & $-5.039 * * *$ & $-5.304 * * *$ \\
(in \% of European Industry Size) & {$[1.487]$} & {$[1.355]$} & {$[2.283]$} & {$[0.869]$} & {$[1.328]$} & {$[1.635]$} \\
Ch. \% China Manufacturing & & $0.401 * * *$ & $0.512^{* * *}$ & & & \\
Output & & {$[0.098]$} & {$[0.155]$} & &
\end{tabular}

$0.000 * * *$

[0.000]

Wages

$-0.000 * *$

[0.000]

Lag of Producer Prices

Lag of Ch. Imports China

$0.104 * * *$

[0.026]

$-0.237$

[0.210]

Panel A: IV First Stage Estimation - Dep. Var. is the $\mathbf{y} / \mathbf{y}$ change in (China Import Value in $€$ / European ${ }^{1}$ industry Size)

\begin{tabular}{|c|c|c|c|c|c|c|}
\hline Labor Intensity $*$ Ch. $\%$ China & $0.007 * * *$ & $0.007 * * *$ & $0.006 * * *$ & $0.007 * * *$ & $0.007 * * *$ & $0.008 * * *$ \\
\hline Manfct. Output & {$[0.002]$} & {$[0.002]$} & {$[0.002]$} & {$[0.002]$} & {$[0.002]$} & {$[0.002]$} \\
\hline Ch. \% China Manufacturing & & 0.006 & 0.011 & & & \\
\hline Output & & {$[0.011]$} & {$[0.013]$} & & & \\
\hline \multirow[t]{2}{*}{ Productivity } & & & $0.000^{*}$ & & & \\
\hline & & & {$[0.000]$} & & & \\
\hline \multirow[t]{2}{*}{ Wages } & & & $-0.000^{*}$ & & & \\
\hline & & & {$[0.000]$} & & & \\
\hline \multirow[t]{2}{*}{ Lag of Producer Prices } & & & & & 0.001 & \\
\hline & & & & & {$[0.002]$} & \\
\hline \multirow[t]{2}{*}{ Lag of Ch. Imports China } & & & & & & -0.034 \\
\hline & & & & & & {$[0.041]$} \\
\hline Cragg-Donald Statistic & 12.146 & 12.428 & 7.767 & 10.488 & 11.555 & 12.534 \\
\hline Max Reject Stock-Yogo Crit Value & $15 \%$ & $15 \%$ & $20 \%$ & $15 \%$ & $15 \%$ & $15 \%$ \\
\hline \multicolumn{7}{|l|}{ Level } \\
\hline $1^{\text {st }}$ stage F-statistic & 16.22 & 18.45 & 10.61 & 14.2 & 16.16 & 15.63 \\
\hline Year dummies (both stages) & $\mathrm{y}$ & $\mathrm{n}$ & $\mathrm{n}$ & $\mathrm{y}$ & $\mathrm{y}$ & $\mathrm{y}$ \\
\hline Observations & 7273 & 7273 & 5803 & 4943 & 6613 & 6678 \\
\hline Groups (Destination - NACE) & 618 & 618 & 611 & 436 & 618 & 618 \\
\hline R-Square (first stage within) & 0.03 & 0.01 & 0.02 & 0.04 & 0.03 & 0.04 \\
\hline
\end{tabular}

Notes: ${ }^{1}$ Europe is France, Germany, Italy, United Kingdom, and Sweden. Panel C of Table 4 shows the OLS relation between changes of import values in $€$ from China and European producer prices. Panel B displays two-stage least squares estimations. The dependent variable is the annual change in the logarithm of the producer price at the four-digit NACE (Rev. 1.1) level (ondy granufacturing industries). "Ch. Imports China" is defined as the y/y absolute change in (China import value in $€$ /European industry size). The industry size ss defined as the 1995-2008 average value of European domestic production plus world imports. In columns 2 and 3, "Ch. \% China Manufacturing Output" is the growth rate of manufacturing output in China. Productivity is the wage adjusted labour productivity and wages capture wages and salaries. Column 4 captures only countries in the Eurozone, i.e. France, Germany and Italy Column 5 includes lagged producer price changes and column 6 incorporates lagged changes of Chinese import values. In Panel A the first-stage relation is displayed. The instrument is the sector's labor intensity times "Ch. \% China Manufacturing Output". All estimations include fixed effects by sector. Clustered standard errors (by country) reported in brackets; ${ }^{*}$ significant at $10 \%$; ** significant at $5 \%$; $* * *$ significant at $1 \%$. 
Table 5 - China Import Volume (in kilograms) and European ${ }^{1}$ Prices: OLS and IV Results (Fixed Effects Panel Estimations)

\begin{tabular}{|c|c|c|c|c|c|c|}
\hline Specification & $\begin{array}{c}\text { (1) } \\
\text { with year } \\
\text { dummies }\end{array}$ & $\begin{array}{c}\text { (2) } \\
\text { incl. China } \\
\text { Ind. Growth }\end{array}$ & $\begin{array}{c}\text { (3) } \\
\text { incl. China } \\
\text { Ind. Growth/ } \\
\text { Productivity \& Wages }\end{array}$ & $\begin{array}{c}(4) \\
\text { Eurozone } \\
\text { countries } \\
F R, I T, D E\end{array}$ & $\begin{array}{c}\text { (5) } \\
\text { Lagged Prices }\end{array}$ & $\begin{array}{c}\text { (6) } \\
\text { Lagged Ch. } \\
\text { Imports LWC }\end{array}$ \\
\hline \multicolumn{7}{|c|}{ Panel C: OLS - Dep. Var. is the $y / y$ Ln-change in Producer Prices } \\
\hline Ch. Imports China & $-0.110 * * *$ & $-0.129 * * *$ & $-0.125^{* * *}$ & -0.108 & $-0.083^{* *}$ & $-0.103 * * *$ \\
\hline (in \% of European Industry Size) & {$[0.039]$} & {$[0.042]$} & {$[0.023]$} & {$[0.071]$} & {$[0.037]$} & {$[0.032]$} \\
\hline Ch. \% China Manufacturing & & $0.241 * * *$ & $0.264 * * *$ & & & \\
\hline Output & & {$[0.034]$} & {$[0.038]$} & & & \\
\hline \multirow[t]{2}{*}{ Productivity } & & & 0.000 & & & \\
\hline & & & {$[0.000]$} & & & \\
\hline \multirow[t]{2}{*}{ Wages } & & & 0.000 & & & \\
\hline & & & {$[0.000]$} & & & \\
\hline \multirow[t]{2}{*}{ Lag of Producer Prices } & & & & & $0.073 * * *$ & \\
\hline & & & & & {$[0.025]$} & \\
\hline \multirow[t]{2}{*}{ Lag of Ch. Imports China } & & & & & & -0.050 \\
\hline & & & & & & {$[0.024]$} \\
\hline Within R-Square & 0.11 & 0.03 & 0.05 & 0.11 & 0.13 & 0.12 \\
\hline \multicolumn{7}{|c|}{ Panel B: IV Second Stage Estimation - Dep. Var. is the $y / y$ Ln-change in Producer Prices } \\
\hline Ch. Imports China & $-2.291 * * *$ & $-2.200^{* * *}$ & $-2.673 * * *$ & $-1.913 * * *$ & $-2.374 * * *$ & $-2.410 * * *$ \\
\hline (in \% of European Industry Size) & [0.493] & {$[0.431]$} & [0.639] & {$[0.497]$} & {$[0.433]$} & {$[0.566]$} \\
\hline Ch. \% China Manufacturing & & $0.353 * * *$ & $0.400 * * *$ & & & \\
\hline Output & & {$[0.055]$} & {$[0.064]$} & & & \\
\hline \multirow[t]{2}{*}{ Productivity } & & & $0.000^{* *}$ & & & \\
\hline & & & {$[0.000]$} & & & \\
\hline \multirow[t]{2}{*}{ Wages } & & & 0.000 & & & \\
\hline & & & {$[0.000]$} & & & \\
\hline \multirow[t]{2}{*}{ Lag of Producer Prices } & & & & & $0.070^{* * *}$ & \\
\hline & & & & & {$[0.019]$} & \\
\hline Lag of Ch. Imports China & & & & & & $-0.273 * * *$ \\
\hline
\end{tabular}

$[0.048]$

Panel A: IV First Stage Estimation - Dep. Var. is the y/y change in (China Import Volume in kilograms / European industry Size)

\begin{tabular}{|c|c|c|c|c|c|c|}
\hline Labor Intensity * Ch. \% China & $0.020^{* * *}$ & $0.020^{* * *}$ & $0.020^{* * *}$ & $0.018^{* * *}$ & $0.020 * * *$ & $0.021^{* * *}$ \\
\hline Manfct. Output & {$[0.003]$} & {$[0.003]$} & {$[0.004]$} & {$[0.005]$} & {$[0.003]$} & {$[0.003]$} \\
\hline Ch. \% China Manufacturing & & $-0.041 * *$ & $-0.044 * *$ & & & \\
\hline Output & & {$[0.013]$} & {$[0.012]$} & & & \\
\hline \multirow[t]{2}{*}{ Productivity } & & & 0.000 & & & \\
\hline & & & {$[0.000]$} & & & \\
\hline \multirow[t]{2}{*}{ Wages } & & & 0.000 & & & \\
\hline & & & {$[0.000]$} & & & \\
\hline \multirow[t]{2}{*}{ Lag of Producer Prices } & & & & & 0.000 & \\
\hline & & & & & {$[0.002]$} & \\
\hline \multirow[t]{2}{*}{ Lag of Ch. Imports China } & & & & & & $-0.097 * * *$ \\
\hline & & & & & & {$[0.006]$} \\
\hline Cragg-Donald Statistic & 49.408 & 48.065 & 42.4 & 33.238 & 46.957 & 52.855 \\
\hline Max Reject Stock-Yogo Crit Value & $10 \%$ & $10 \%$ & $10 \%$ & $10 \%$ & $10 \%$ & $10 \%$ \\
\hline \multicolumn{7}{|l|}{ Level } \\
\hline $1^{\text {st }}$ stage F-statistic & 44.63 & 43.67 & 30.41 & 15.62 & 53.38 & 49.96 \\
\hline Year dummies (both stages) & $\mathrm{y}$ & $\mathrm{n}$ & $\mathrm{n}$ & $\mathrm{y}$ & $\mathrm{y}$ & y \\
\hline Observations & 5104 & 5104 & 4072 & 3465 & 4637 & 4682 \\
\hline Groups (Destination - NACE) & 434 & 434 & 429 & 305 & 434 & 434 \\
\hline R-Square (first stage within) & 0.05 & 0.03 & 0.03 & 0.06 & 0.05 & 0.08 \\
\hline
\end{tabular}

Notes: ${ }^{1}$ Europe is France, Germany, Italy, United Kingdom, and Sweden. Panel C of Table 4 shows the OLS relation between changes of import volume (in kilograms) from China and European producer prices. Panel B displays two-stage least squares estimations. The dependent variable is the annual change in the logarithm of the producer price at the four-digit NACE (Rev. 1.1) level (only manufacturing industries). "Ch. Imports China" is defined as the $\mathrm{y} / \mathrm{y}$ absolute change in (China import volume in $\mathrm{kg}$ /European industy Size). The industry size is defined as the 1995-2008 average value of European domestic production plus world imports. In columns 2 and 3, "Ch. \% China Manufacturing Output" is the gro wth rate of manufacturing output in China. Productivity is the wage adjusted labour productivity and wages capture wages and salaries. Column 4 captures only countries in the Eurozone, i.e. France, Germany and Italy. Column 5 includes lagged producer price changes and column 6 incorporates lagged changes of Chinese import volumes. In Panel A the first-stage relation is displayed. The instrument is the sector's labor intensity times "Ch. \% China Manufacturing Output". All estimations include fixed effects by sector. Clustered standard errors (by country) reported in brackets; ${ }^{*}$ significant at $10 \%$; ${ }^{*}$ significant at $5 \%$; ${ }^{* * *}$ significant at $1 \%$. 


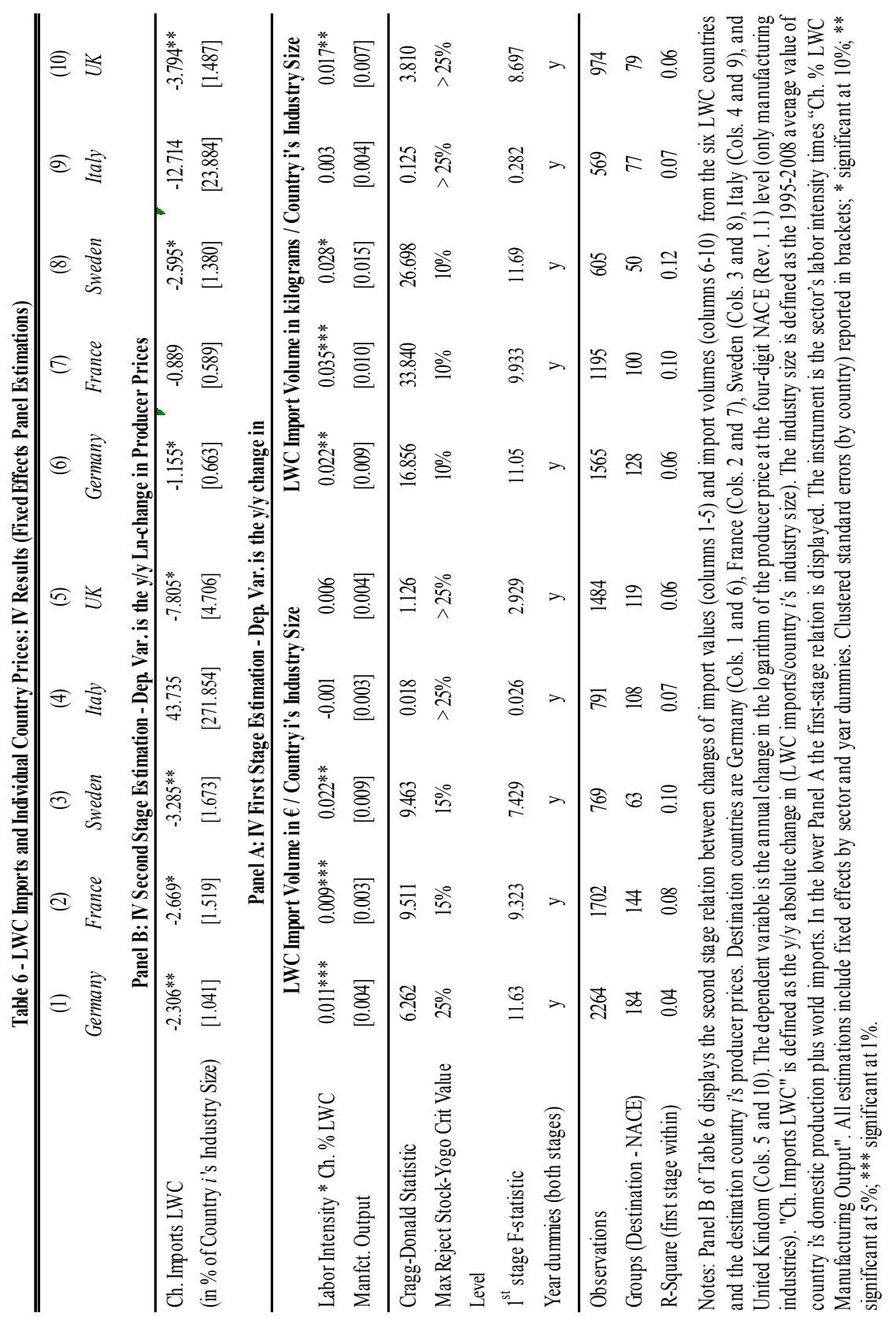




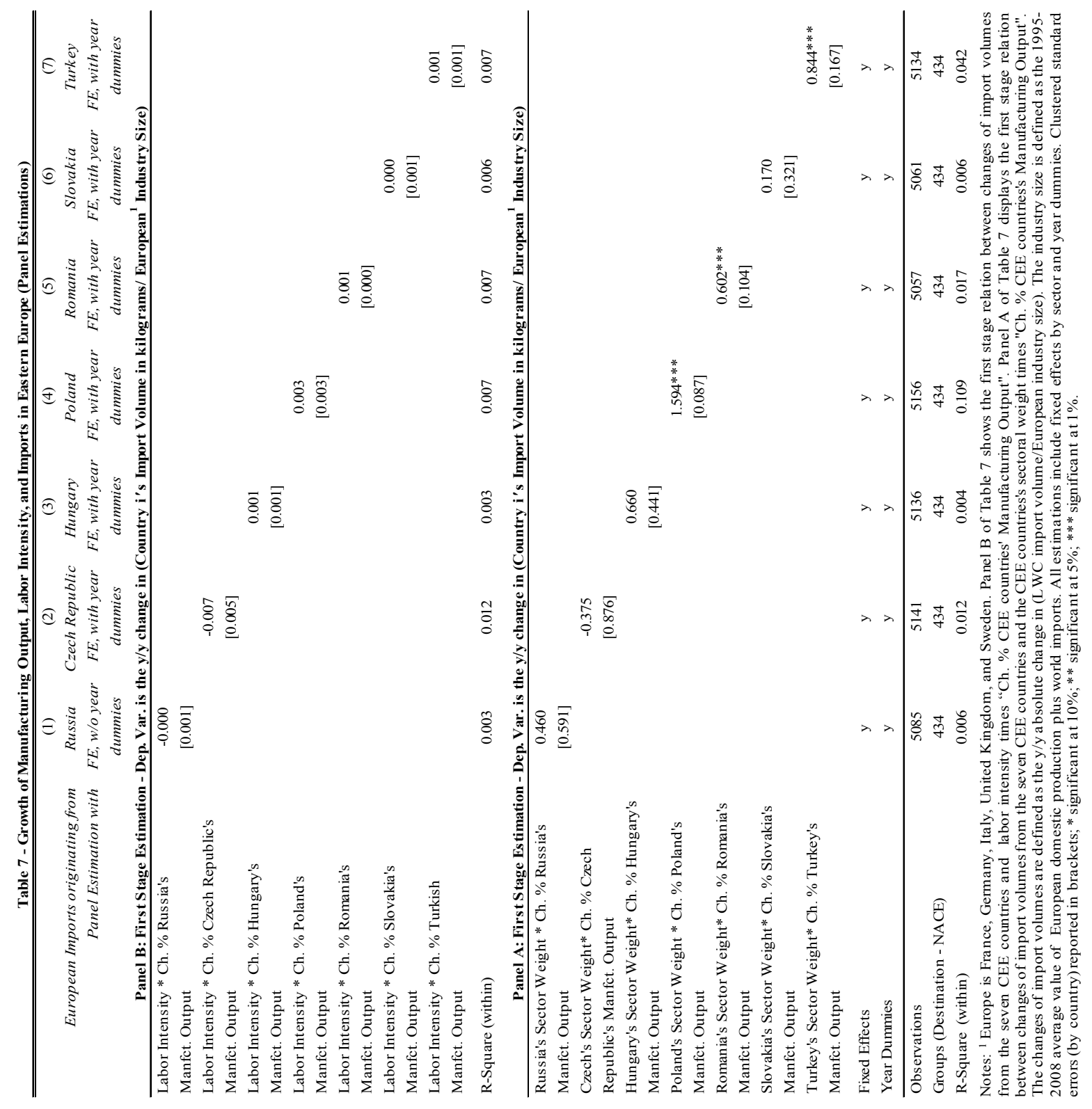

